\title{
Consumption of Entrained Gases Within Bifilms During a Mg-Alloy Casting Process
}

\author{
TIAN LI, J.M.T. DAVIES, and DAN LUO
}

The formation of entrainment defects, (also known as double oxide film defects or bifilms), caused by the entrapment of a doubled-over surface oxide film containing a small amount of local atmosphere, has been investigated by combining practical experiments using a commercial-purity $\mathrm{Mg}$-alloy under protective gases, with theoretical thermodynamic calculations. Evolution of the entrainment defects was studied, and a double-layered structure of their oxide films was found, which was different from the single-layered structure of the Mg-alloy melt surface films that have been previously reported. A pore gas analyzer was used to analyze the gas trapped within the defects from which $\mathrm{H}_{2}$ and $\mathrm{N}_{2}$ (from the air) were detected. It was found that entrapped gases can be depleted through reactions with the surrounding liquid Mg-alloy, resulting in the oxide films growing together in the melt. Transformation of the entrained gas to solid-phase compounds could reduce the void volume of the defects, thus probably diminishing the negative effect of the entrainment defects on the quality of castings.

https://doi.org/10.1007/s11663-021-02237-z

(C) The Author(s) 2021

\section{INTRODUCTION}

THE global demand of Mg-alloys has been increasing in recent years, ${ }^{[1-6]}$ motivating a wide interest in using Mg-alloy castings for automotive components. ${ }^{[6]}$ However, the mechanical properties and reproducibility of Mg-alloy castings are commonly affected by the defects formed during the casting process. For example, entrainment defects (also known as double oxide film defects or bifilms), which are a major factor affecting the reproducibility and the eventual properties of light alloy castings, ${ }^{[7-10]}$ have been found in Mg-alloy castings. ${ }^{[8,9]}$ As shown in Figure 1, entrainment of a small amount of local atmosphere into the melt can form significant defects during the casting process, which is the key factor affecting the variable nature of the casting properties. ${ }^{[7,10]}$

The entrained gas could be consumed through reaction with the surrounding melt, which was firstly reported in Al-alloy castings, ${ }^{[10]}$ therefore causing the double oxide layers of the defect to recombine to "heal"

TIAN LI is with the University of Birmingham, Birmingham, B15 2TT, UK and with the Grainger and Worrall Ltd, Stanmore Industrial Estate, Bridgnorth WV15 5HP, UK. J.M.T. DAVIES is with the University of Birmingham. DAN LUO is with the Department of Materials Science and Engineering, the University of Sheffield, Sir Robert Hadfield Building, Mappin St, Sheffield, S1 3JD, UK. Cotact email: d.luo@sheffield.ac.uk

Manuscript submitted February 12, 2021; accepted May 25, 2021.

Article published online June 28, 2021. the defect. ${ }^{[1]}$ To improve the quality of Al castings, Raidszadeh and Griffiths ${ }^{[12]}$ increased the melt holding time to allow the entrained gas to react sufficiently with the surrounding Al-alloy melt in effort to reduce the void volume within entrainment defects. They reported a bonding of the double oxide films based on a link between the two oxide surfaces within the defect. However, the increase of the reproducibility of their Al-alloy castings with a long holding time was not significant, probably because the nitrogen contained in the entrained gas (i.e., 78 pct of air) was very difficult to react with liquid Al-alloys. ${ }^{[13,14]}$

As compared with Al-alloys, a liquid Mg-alloy more readily reacts with the common constituents of entrained atmospheres, especially with nitrogen, which is referred to as "nitrogen burning" in $\mathrm{Mg}$ casting industry. ${ }^{[15]}$ Thus the void volume of entrainment defects within $\mathrm{Mg}$-alloy castings may be relatively easier to reduce due to this entrained gas consumption. The oxide film bonding of entrainment defects, reported by Raidszadeh and Griffiths, ${ }^{[12]}$ may also occur in Mg-alloy castings. However, a cover gas was required for a $\mathrm{Mg}$-alloy casting process to avoid the $\mathrm{Mg}$-alloy ignition. Thus the entrained gas in a Mg-alloy casting may contain the cover gas used during the casting process, rather than air only, further complicating the defect evolution process.

$\mathrm{SF}_{6}$ is a typical cover gas widely used for $\mathrm{Mg}$-alloy casting processes. ${ }^{[16-18]}$ Although this cover gas has been restricted in European Mg-alloy foundries, it is still popular in the global Mg-alloy industry, especially in the 

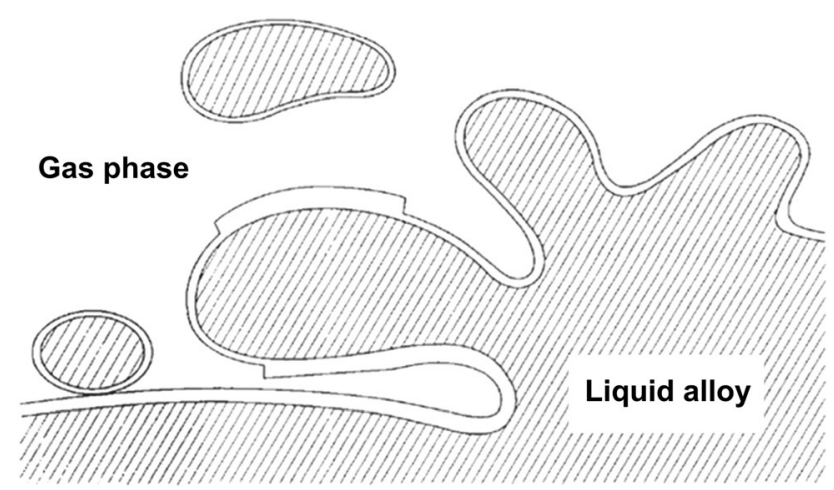

Fig. 1-Sketch of surface entrainment event in a light alloy casting (reprinted from Ref. 8).

countries who dominated the global Mg-alloy production, such as China, Brazil, India, etc. ${ }^{[19]}$ The $\mathrm{SF}_{6}$ cover gas forms a protective film on top of the melt which has been studied in previous works and reported to be a simple-structured surface film composing of $\mathrm{MgF}_{2} /$ $\mathrm{MgO} \cdot{ }^{[18,20-23]}$ However, an unlimited cover gas supply was continually directed onto the melt surface in these studies, which is different from the situation of gas entrainment within defects, where the amount of entrained gas was finite, hence allowing the carrier gas to eventually deplete. Therefore, although entrainment defects have been found in Mg-alloy castings, ${ }^{[9]}$ with their negative effects confirmed by Griffiths and Lai, ${ }^{[8]}$ research into their behavior and evolution is still limited.

This study investigated (using experimental and theoretical approaches) the entrained gas consumption and its effect in the casting of a commercial-purity $\mathrm{Mg}$-alloy under the protection of a $\mathrm{SF}_{6}$ cover gas.

\section{EXPERIMENTAL PROCEDURES}

\section{A. Melting and Casting}

Three kilograms of commercial-purity Mg-alloy were melted in a mild-steel crucible $(\phi 20 \mathrm{~cm} \times 30 \mathrm{~cm})$ of a medium-frequency induction furnace under the protection of 0.5 pct $\mathrm{SF}_{6} /$ air at the flow rate of $6 \mathrm{~L} / \mathrm{min}$. The temperature was kept at $700{ }^{\circ} \mathrm{C} \pm 5{ }^{\circ} \mathrm{C}$ when the alloy was completely melted. The melt was then degassed by a lance degasser using argon at $0.3 \mathrm{~L} / \mathrm{min}$ for $15 \mathrm{~min}$ utes. ${ }^{[24,25]}$ After degassing, the oxides on the melt surface were skimmed off, and the melt was then poured into a sand mold.

The sand molds for the castings were made from silica sand bonded with resin (1 wt pct PEPSET 5230 resin + 1 wt pct PEPSET 5112 catalyst), with dimensions as shown in Figure 2. The sand also contained $2 \mathrm{wt}$ pct $\mathrm{Na}_{2} \mathrm{SiF}_{6}$ acting as an inhibitor. ${ }^{[26,27]}$ Commercial-purity $\mathrm{Mg}$-alloy ingots were used in this experiment. Prior to pouring, the sand mold was flushed with the cover gas 0.5 pct $\mathrm{SF}_{6} /$ air at $6 \mathrm{~L} / \mathrm{min}$ for $20 \mathrm{~min}$. Then the melt was then poured at $700 \pm 5{ }^{\circ} \mathrm{C}$ under the protection of the same gas. The castings were machined into 40 test bars for a tensile strength test, using a Zwick 1484 tensile test machine with a clip extensometer. The fracture surfaces of the broken test bars were examined using Scanning Electron Microscope (SEM, Philips JEOL7000) with an accelerating voltage of $5-15 \mathrm{kV}$. The residual melt (around $1 \mathrm{~kg}$ ) was solidified in the crucible and sectioned into small pieces, polished, and examined using SEM.

\section{B. Oxidation Cell}

To better understand the effects of $\mathrm{SF}_{6}$ cover gas consumption within an entertainment defect (i.e., a finite amount of cover gas), through reactions with the surrounding melt, a mild-steel oxidation cell was designed for this experiment as shown in Figure 3.

The cover gases contained in the sealed oxidation cell was regarded as a large-size entrained 'gas bubble'. The internal diameter of the cell was $32 \mathrm{~mm}$ and the length, $400 \mathrm{~mm}$. A temperature difference was created between the upper and lower sections of the cell to promote gas mixing via convection. This was achieved using a water-cooled copper tube coiled around the upper half of the cell. At the start of the experiment, commercial-purity $\mathrm{Mg}$ was heated in a magnesia crucible and kept at $100{ }^{\circ} \mathrm{C}$ in an electric resistance furnace, under the protection of $0.5 \mathrm{pct} \mathrm{SF}_{6} /$ air (at a flow rate of $1 \mathrm{~L} /$ $\mathrm{min}$ ), for $20 \mathrm{~min}$ to displace the trapped atmosphere/air within the oxidation cell. The temperature was then raised to $700 \pm 5{ }^{\circ} \mathrm{C}$ to melt the $\mathrm{Mg}$ at which point both inlet and exit valves were closed, thereby limiting the amount of cover gases available, hence creating a sealed environment for oxidation to occur. The samples were then left to oxidize for different amounts of holding times, from 5 to 30 minutes at 5-minute intervals, before being quenched in water to room temperature. For comparison, 0.5 pet $\mathrm{SF}_{6} / \mathrm{CO}_{2}$ was also used in the oxidation cell experiment. The oxidized samples were subsequently sectioned and examined by SEM with an accelerating voltage of 5 to $15 \mathrm{kV}$.

\section{Pore Gas Analysis}

Samples from sand castings were initially examined using a real time X-ray radiography set to search for sections containing a trapped gas bubble. To fit the size of the chamber of the pore gas analyser, the sand casting was produced using a different sand mold, as shown in Figure 4 . The melting and casting processes were the same as described in Section II-A.

The sample containing a gas bubble was placed into in the fracture chamber of the pore gas analyser, as shown in Figure 5. Through operation of pump P1 (with valve V1 open and valve V2 closed), the pressure within the system was reduced to $10^{-6}$ mbar. A needle was subsequently driven through the surface layer above the pore, releasing the trapped gas into the system. The released gas from the pore was then drawn through the mass spectrometer (Hiden Analytical Limited HMT quadrupole mass spectrometer) by pump P1 and analyzed. 

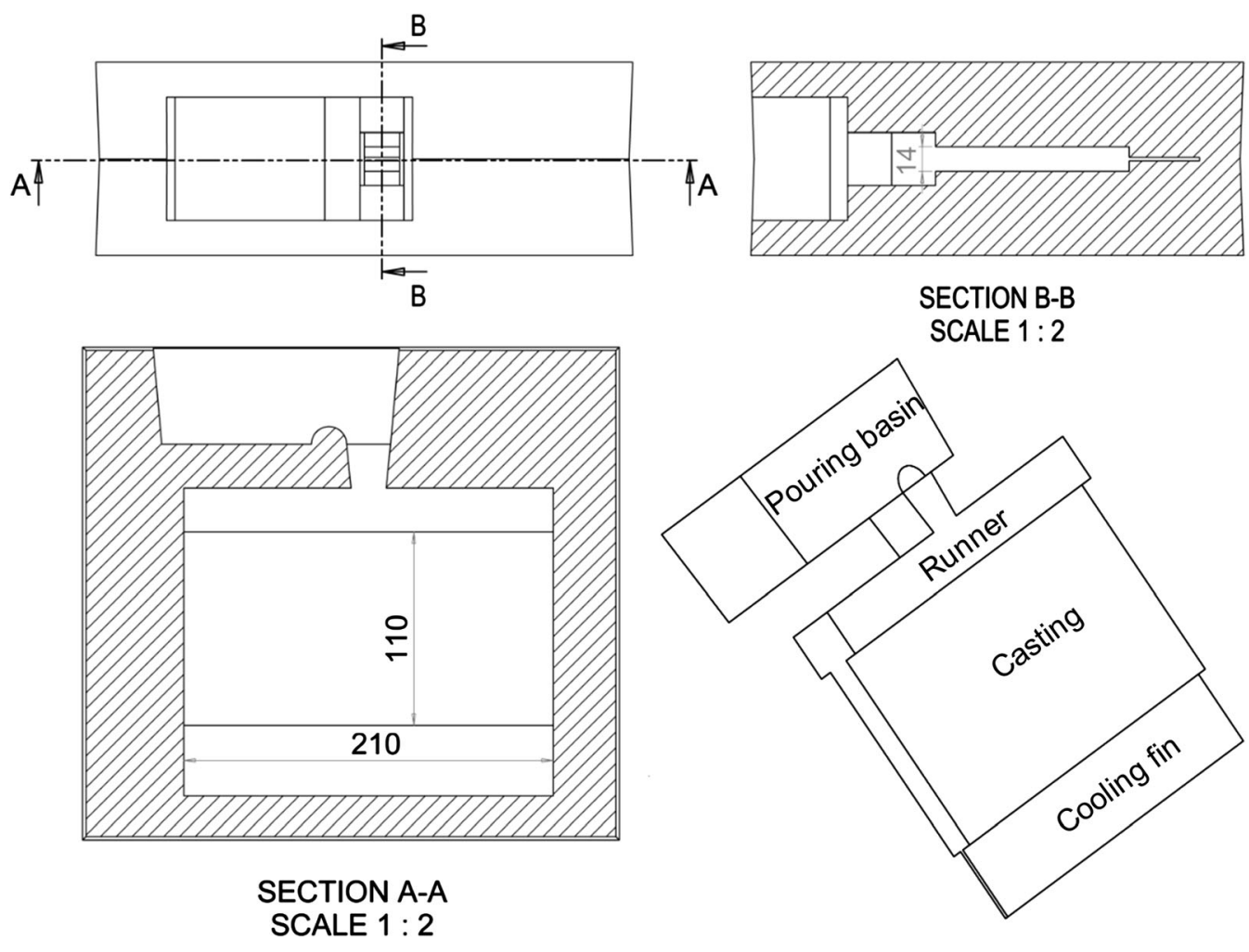

Fig. 2-Dimensions of the sand mold used for casting test bars (unit: $\mathrm{mm}$ ).

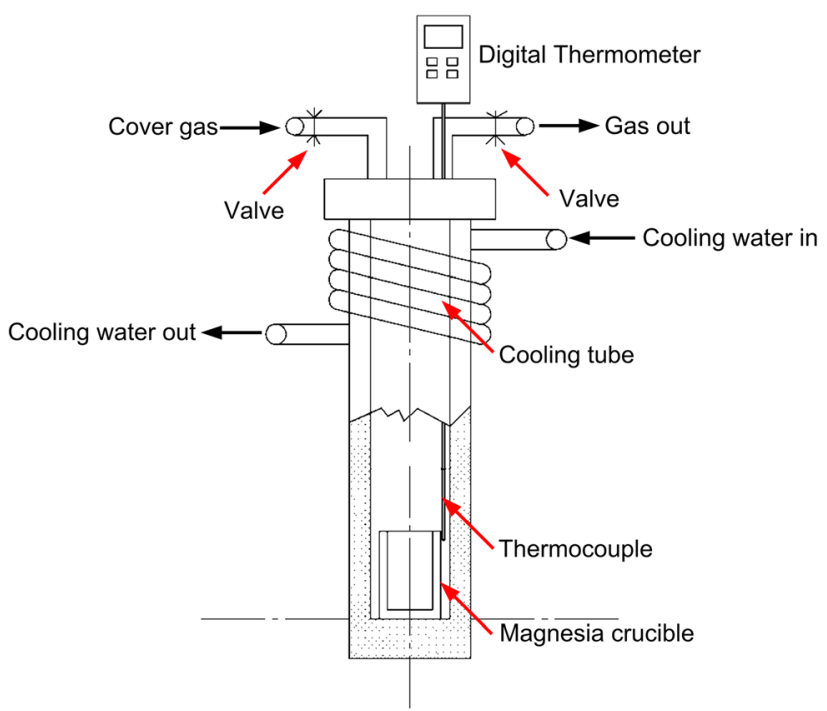

Fig. 3-Schematic of the oxidation cell (reprinted from Ref. 19).

\section{The Effect of Carrier Gases}

As previously mentioned, Raidszadeh and Griffiths ${ }^{[12]}$ tried to increase the consumption rate of the entrained gases by extending the melt holding time (10 to 60 minutes) to allow the entrained gases to react sufficiently with the surrounding Al-alloy melt. However, this technique is not suitable for the practical casting process, especially for the Mg-alloy sand casting process. It is not practical to hold the $\mathrm{Mg}$-alloy in a sand mold at liquidus status for over $10 \mathrm{~min}$.

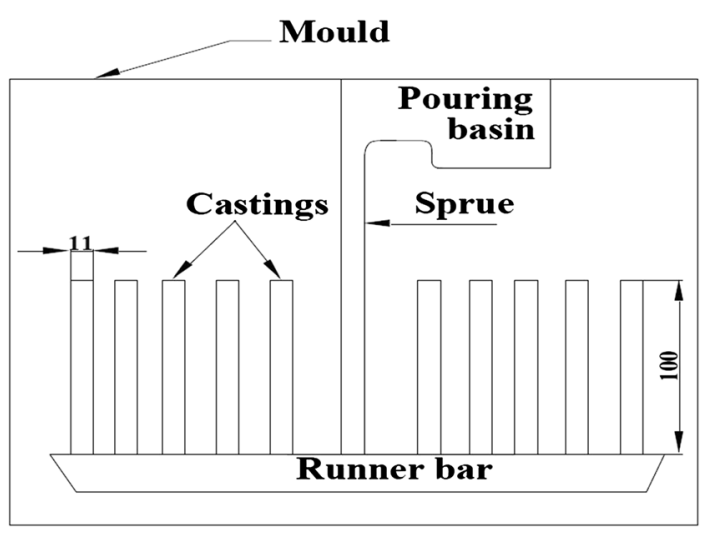

Fig. 4-Dimensions of the sand mold for pore gas analysis (unit: $\mathrm{mm}$ ) (reprint from Ref. 28).

Therefore, another trial based on a $\mathrm{SF}_{6} / \mathrm{CO}_{2}$ cover gas was conducted for comparison with this work. $\mathrm{CO}_{2}$ was widely recommended as a carrier gas for $\mathrm{Mg}$-alloy casting process, since $\mathrm{CO}_{2}$ is more protective and reacts less than air. $\mathrm{SF}_{6} /$ air required a higher content of $\mathrm{SF}_{6}$ as compared with $\mathrm{SF}_{6} / \mathrm{CO}_{2}$, to avoid the ignition of molten magnesium. ${ }^{[22]}$ This different protectability of the carrier gases suggests that an entrained gas of $\mathrm{SF}_{6} /$ air may be consumed faster than that of $\mathrm{SF}_{6} / \mathrm{CO}_{2}$, which may affect the size and void volume of the entrainment defects contained in the final $\mathrm{Mg}$-alloy castings. Therefore, the experiments described in Sections II-A to II-B were repeated using a cover gas of $0.5 \mathrm{pct} \mathrm{SF} / \mathrm{CO}_{2}$, to further investigate the effect of carrier gases on the corresponding entrainment defects and casting properties. 


\section{RESULTS}

\section{A. Structures of Entrainment Defects Formed in Mg-Alloy Castings}

Figure 6(a) shows a typical pore defect found in the commercial-purity $\mathrm{Mg}$-alloy casting under the protection of 0.5 pet $\mathrm{SF}_{6} /$ air. Only $\mathrm{MgO}$ was detected in the inner section of this defect from the EDS result (Figure 6(b)). A compact and single-layered oxide film can be seen (Figure 6(c)) and was mainly composed of $\mathrm{MgO}$ and $\mathrm{MgF}_{2}$ (Figure 6(d)). The existence of a small amount of fluorides in the oxide film suggested that this pore defect was an entrainment defect from $\mathrm{SF}_{6}$ cover gas, rather than a shrinkage defect or hydrogen gas porosity.

Another different type of entrainment defect also existed in the same casting, which showed that the oxide film grew together in Figure 7(a). A sandwich-like structure can be seen in this defect from the Figure 7(b): a porous inner section mainly consisting of $\mathrm{MgO}$ (Figure 7(c)), and compact double outer layers composing of $\mathrm{MgF}_{2}$ only (Figures 7(e) through (h)). Fluorine and sulfur were also detected in the porous inner section, in relatively small amounts.

To better understand the defects, the fracture surface was further investigated, rather than only the two-dimensional observations from the cross sections of the entrainment defects shown in Figures 6 and 7. A pair of fracture surfaces of a tensile test bar is presented in Figure 8(a). Symmetrical dark regions can be seen on both the fracture surfaces. Figure 8(b) shows a local magnified section of the boundary between the dark and bright regions from Figure 8(a). The bright region was relatively rough and full of ridges and lines, while the dark region was comparatively smooth and of a wrinkled nature. The EDS results (Table I) of the sample shows that fluorine was only detected in the dark regions, and the corresponding oxygen content was relatively high, indicating that the dark regions were oxide surface films entrained into the melt. White granules were observed in the oxide film from the further magnified examination (Figure 8(c)), which indicated that the oxide films on each of the fracture surfaces may be separated prior to the fracture of the test bar. Hence a small amount of entrained gas may

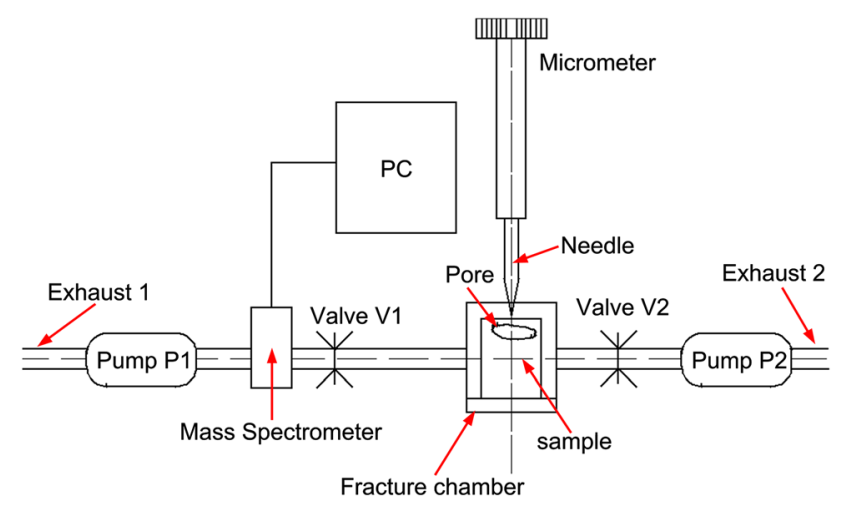

Fig. 5-Schematic of the pore gas analyser. have existed between the double oxide films. In conjunction with their symmetrical and wrinkled nature, it can be suggested that the dark regions were an entrainment defect, which may have contained an entrained gas.

Observations of entrainment defects from both cross sections (Figure 6) and the fracture surfaces (Figure 8) suggested how the symmetrical oxide films on the facture surfaces were formed. As shown in Figure 9(a), an entrainment defect existed in the test bar. Prior to the fracture, the cross-sectional morphology of the entrainment defects was similar with that shown in Figure 6.

During the fracture, the entrainment defect acts as the crack initiator. ${ }^{[10]}$ The crack can also grow following the weakest path ${ }^{[29]}$ (i.e., the entrainment defect), causing the facture to develop in the middle of the entrainment defect. Therefore, the double oxide films of the entrainment defect remained on opposite fracture surfaces after failure (Figure 9b).

Another entrainment defect located on fracture surfaces are shown in Figure 10(a), which contains nitrides in the oxide film (Figure 10(b)). The morphology (Figure 10(c)) of this oxide film was similar to that of the film shown in Figure 8(c). Al and $\mathrm{Si}$ were also detected, which might come from the ingot impurities and the sand mold, respectively. Nitrides were only detected on the fracture surfaces of test bars and were not found in the water-polished samples such as Figures 6 and 7. This may be because the nitrides hydrolyzed easily, leading to the escape of $\mathrm{N}$ in the form of $\mathrm{NH}_{3}$ during the sample preparation process (i.e., water polishing). ${ }^{[30]}$

\section{B. Oxidation Cell}

The entrainment defects shown in Section III-A had different structures and contained different combination of compounds, which may be related to different stages of the reactions between liquid $\mathrm{Mg}$-alloy and entrained 0.5 pet $\mathrm{SF}_{6} /$ air cover gases. However, the reaction between $\mathrm{Mg}$-alloy melt and the entrapped cover gases were rarely reported. Previous studies regarding the protection of liquid Mg-alloys using cover gases ${ }^{[18,20-23]}$ were carried out with an unlimited amount of cover gases, which was different from the situation of an entrained gas. Therefore, an oxidation cell under limited cover gases (similar to entrained gases) was used to investigate the evolutionary behavior of entrainment defects.

The commercial-purity $\mathrm{Mg}$-alloy was held at $700{ }^{\circ} \mathrm{C}$ in the oxidation cell for 0 to 30 minutes with $\mathrm{SF}_{6} /$ air cover gases, as shown in Figure 11. Figure 11(a) shows the surface oxide film held for 0 min (i.e., the oxidation cell was quenched, once its temperature reached $700{ }^{\circ} \mathrm{C}$ ) and its EDS element map. This oxide film was primarily composed of a single layer of $\mathrm{MgF}_{2}$. Figure 11(b) shows the surface film held for $5 \mathrm{~min}$. This surface film had two layers; a thick bottom layer (i.e., in contact with the $\mathrm{Mg}$ substrate) enriched with fluorine, and a thin top layer (i.e., in contact with the Bakelite) enriched with sulfur. Oxygen was detected in the S-enriched layer, but its content in the bottom layer (i.e., the F-enriched layer) 

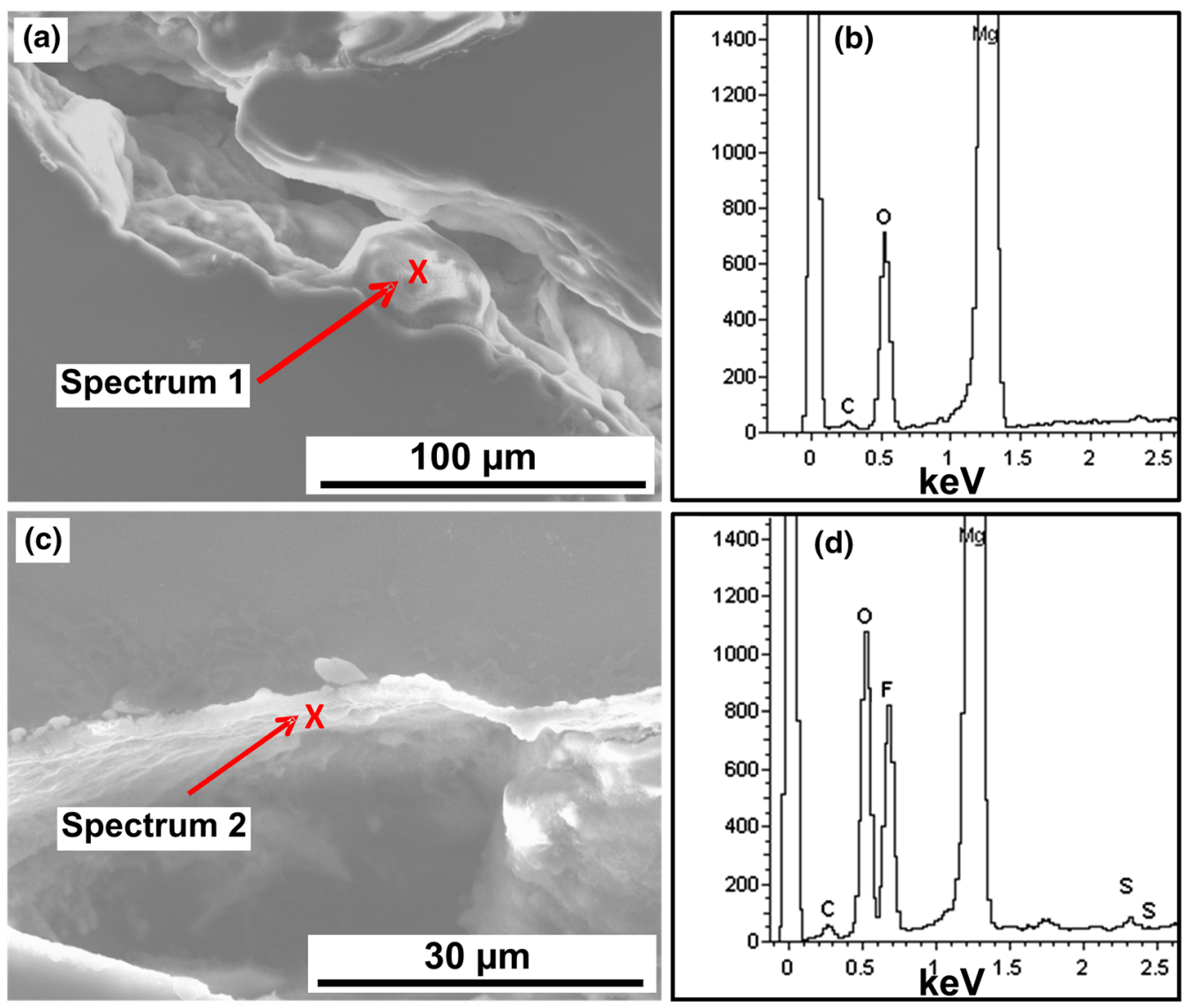

Fig. 6- (a) A typical entrainment defect in the commercial-purity Mg-alloy casting under the protection of 0.5 pct SF6/air, (b) EDS result of spectrum 1, (c) local magnified outside layer of film, and $(d)$ EDS of spectrum 2.

was too low to be identified by EDS. The films held for 5- 25 min had similar double-layered structures, and the thickness of the S-enriched layer increasing with an increased holding time. Figure 11(c) shows a surface film held for 30 min. Oxygen and magnesium were detected in both the layers.

The multiple-layer structure and the different thickness of the S-containing layers suggested that the fluorides in the cover gases were preferentially consumed to form the F-enriched bottom layer in the early stage of the holding experiment. After the fluorides were depleted, the Mg-alloy melt further reacted with the residual cover gases to form the S-containing top layer. It should be noted that this formation process is different from that of the Mg-alloy surface film reported in previous studies. ${ }^{[18,20-23]}$ Pettersen et al. ${ }^{[21]}$ suggested that the liquid $\mathrm{Mg}$-alloy firstly reacted with oxygen, forming a thin $\mathrm{MgO}$ film, and then $\mathrm{SF}_{6}$ dissociated to provide atomic fluorine, which could penetrate through the porous $\mathrm{MgO}$ layer, forming an inner $\mathrm{MgF}_{2}$ layer. Xiong and $\mathrm{Liu}^{[20]}$ found different-colored regions on the surface of the protective film. Their EDX results suggested that the discolored regions corresponded to $\mathrm{MgF}_{2}$ particles under the surface film. In addition, Xiong and Wang ${ }^{[18]}$ reported that the discolored regions appeared after the formation of a preliminary $\mathrm{MgO}$ film, giving support to Pettersen's process.
The difference between this experiment and those of previous studies was that this investigation used a limited cover gas supply, whereas other studies investigated the use of an unlimited cover gas supply, potentially allowing for the fluorides in the system to be consumed.

This double-layered oxide film also existed in the sandwich-like structure shown in Figure 7 (i.e., an outer layer enriched with $\mathrm{MgF}_{2}$, and inner part enriched with $\mathrm{MgO}$ ). The $\mathrm{MgO}$ features that are shown in Figure 6(a) may also form due to the depletion of fluorides and sulfur in the entrained gas. The structure of these defects suggests that the entrained gas in the defect was consumed through the reactions with the surrounding liquid magnesium, and that the double oxide films grew simultaneously.

\section{Pore Gas Analyser}

The studies in Sections III-A to III-B only focused on the oxide films of the entrainment defects. However, the entrained gas was also worth investigating. It was widely suggested that pore defects in Al-alloy and Mg-alloy castings contained hydrogen that diffused from the melt. ${ }^{[10,24,25,31]}$ In addition, Campbell ${ }^{[10]}$ conjectured that hydrogen was able to diffuse from an Al-alloy melt into an entrainment defect, resulting in 

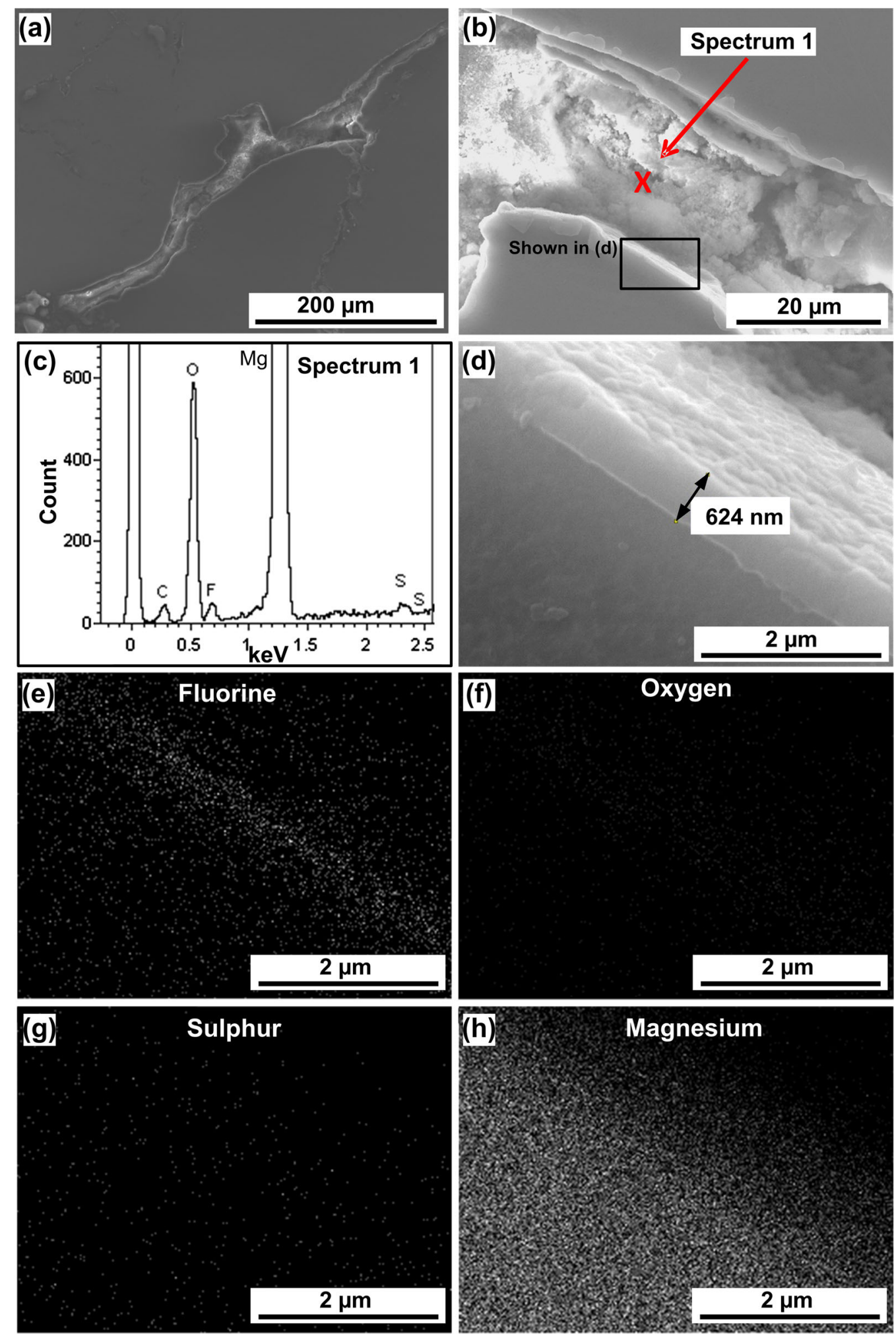

Fig. 7- (a) Another entrainment defect found in the commercial-purity Mg alloy casting, $(b)$ the inner section of the defect indicated that the oxide films had grown together, (c) EDS spectrum of the point denoted in (b), (d) a magnified observation edge of the defect, showing a compact single-layer oxide film, $(e)$ through $(h)$ element maps of the area shown in (d).

expansion of the defect. Yue and Griffiths observed pore defect expansion when re-melting a liquid A356 alloy sample under Synchrotron X-rays. ${ }^{[32]}$ However, there is no further direct evidence to indicate that the expansion was caused by diffused hydrogen (rather than another gas) into the defect. Therefore, pore gas analysis was 

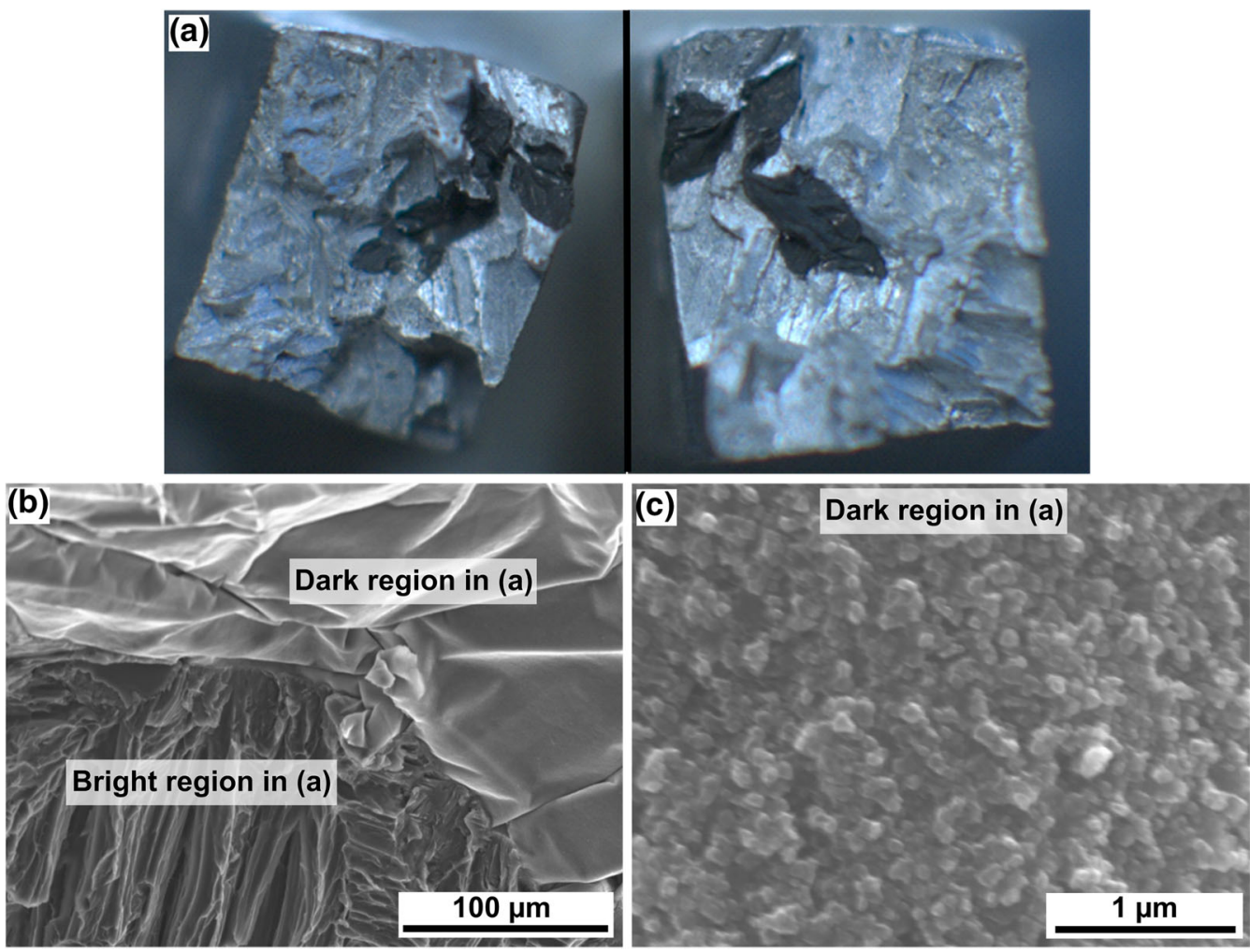

Fig. 8- (a) A entrainment defect on the fracture surfaces of a commercial-purity Mg alloy test bar; $(b)$ a local magnified section of the boundary between the dark and bright regions, and $(c)$ a further magnified observation to the surface of the dark region. The dimension of the fracture surface is $5 \mathrm{~mm} \times 6 \mathrm{~mm}$. The acceleration voltage was $15 \mathrm{kV}$.

Table I. EDS Results Corresponding to Bright and Black Regions in Fig. 8

\begin{tabular}{lcccccc}
\hline Cover Gases & $\mathrm{C}$ & $\mathrm{O}$ & $\mathrm{Mg}$ & $\mathrm{F}$ & $\mathrm{S}$ & $\mathrm{N}$ \\
\hline $\mathrm{SF}_{6} /$ Air (Wt Pct) & & & & & & \\
Dark Region & 2.62 & 2.84 & 94.00 & 0.54 & - & - \\
Bright Region & 3.72 & 0.53 & 95.74 & - & - & - \\
\hline
\end{tabular}

carried out to measure the gas composition contained in the pore defects that were formed in the Mg-alloy casting.

Figure 12(a) is an X-ray image showing gas bubbles contained in the commercial-purity $\mathrm{Mg}$-alloy cast under $\mathrm{SF}_{6} /$ air. The mass spectrometer of the pore gas analyser was only able to detect the compounds with a molecular mass less than 100, and accordingly could not recognize $\mathrm{SF}_{6}$ and some of its decomposition products (i.e., molecular mass $\mathrm{SF}_{6}=146, \mathrm{SF}_{5}=127, \mathrm{SF}_{4}=108$. etc.). Therefore, the setting of the proposed compounds for this pore gas analysis were $\mathrm{H}_{2}($ molecular mass $=2)$, $\mathrm{N}_{2}$ (molecular mass $\left.=28\right), \mathrm{O}_{2}($ molecular mass $=32)$, $\mathrm{F}_{2}($ molecular mass $=38), \mathrm{CO}_{2}($ molecular mass $=44)$, $\mathrm{SO}_{2}($ molecular mass $=64), \mathrm{SF}_{3}($ molecular mass $=89)$.

Figure 12(b) shows the mass spectroscopy result of the trapped gas bubble. Hydrogen and nitrogen were released from the bubble when the sample was pierced by the needle. Oxygen and the decomposition products of $\mathrm{SF}_{6}$ were not detected in the trapped gas. These gases may have been depleted through reactions with the surrounding $\mathrm{Mg}$-alloy melt or may have combined with other elements to form heavier species (with molecular mass greater than 100) and hence became undetectable with this apparatus. The existence of nitrogen in this defect indicated that this pore was an entrainment defect containing an entrained gas, rather than hydrogen porosity. In addition, a relatively high content of hydrogen was also found in the pore gas, demonstrating the $\mathrm{H}$ diffusion phenomenon conjectured by Campbell. ${ }^{[10]}$

\section{The Effect of Carrier Gases}

Figure 13 shows the comparison of the growth rates of the oxide film formed in different cover gases (i.e., $0.5 \mathrm{pct}$ $\mathrm{SF}_{6} /$ air and $\left.0.5 \mathrm{pct} \mathrm{SF}_{6} / \mathrm{CO}_{2}\right) .15$ random points of each sample were selected for the film thickness measurement. The 95 pct confidence interval (95 pctCI) was computed under an assumption that the variation of the film thickness followed a normal distribution. Obviously, the oxide films formed in 0.5 pct $\mathrm{SF}_{6} /$ air grew much faster than those formed in $0.5 \mathrm{pct} \mathrm{SF}_{6} / \mathrm{CO}_{2}$. The different oxide film growth rates suggested that in an entrainment defect with a certain amount of cover gases, 0.5 pct $\mathrm{SF}_{6} /$ air would be consumed faster than 0.5 pct $\mathrm{SF}_{6} / \mathrm{CO}_{2}$.

Figure 14 shows the 2-sigma diagram of the tensile test bars (40 data points for each cover gas) cast in both 0.5 pet $\mathrm{SF}_{6} /$ air and 0.5 pet $\mathrm{SF}_{6} / \mathrm{CO}_{2}$. The black and red rectangles were plotted based on 95 pctCI, as follows. ${ }^{[33]}$ 




(a)



(b)

Fig. 9-Schematic for an entrainment defect contained in the test bar (a) before facture and $(b)$ after fracture.

$$
95 \mathrm{pctCI}=\text { average properties } \pm Z_{0.95} * \mathrm{SE}
$$

where $Z_{0.95}=2$ for the 2-sigma diagram (i.e., 1.96 was the 97.5 pct quantile of the standard Gaussian distribution), and SE denoted the standard error (i.e., sigma). The $\mathrm{H}$ contents of the castings were $0.112 \mathrm{ppm}$ and 0.098 ppm for the $\mathrm{SF}_{6} /$ air and $\mathrm{SF}_{6} / \mathrm{CO}_{2}$ castings, respectively.

The cover gas of $\mathrm{SF}_{6} /$ air would cause more oxides to become contained in the melt compared with $\mathrm{SF}_{6} / \mathrm{CO}_{2}$, due to its relatively low protectability. Therefore, in conjunction with the different $\mathrm{H}$ contents, the mechanical properties of the $\mathrm{SF}_{6} /$ air casting were expected to be slightly lower than the casting protected by $\mathrm{SF}_{6} / \mathrm{CO}_{2}$, without consideration of the entrainment defects.

However, as shown in Figure 14, there was no clear difference between distributions of the UTS data points of the test bars produced under different cover gases, except that the distributions of the elongations data points presented a clear difference. Nearly all of the data points obtained under the protection of $\mathrm{SF}_{6} / \mathrm{CO}_{2}$ falls into the lower black rectangle area, while almost 60 pct data obtained under the protection of $\mathrm{SF}_{6} /$ air were in the same area as the one under the $\mathrm{SF}_{6} / \mathrm{CO}_{2}$. The remaining 40 pct data were obviously above nearly all the data points from the $\mathrm{SF}_{6} / \mathrm{CO}_{2}$, which shows that some test bars produced in 0.5 pct $\mathrm{SF}_{6} /$ air cover gases had statistically higher elongations than the Mg-alloy casting produced in 0.5 pct $\mathrm{SF}_{6} / \mathrm{CO}_{2}$. The relatively high elongation of the casting produced in 0.5 pct $\mathrm{SF}_{6} /$ air could be attributed to the comparatively faster consumption of $\mathrm{SF}_{6} /$ air and therefore diminishing the negative effect of entrainment defects, showing that different carrier gases could influence the final mechanical properties of $\mathrm{Mg}$-alloy casting.

\section{DISCUSSION}

\section{A. Evolution of Entrainment Defects Formed in $\mathrm{SF}_{6} /$ Air}

Entrainment defects, formed in the commercial-purity Mg-alloy casting, were composed of different combinations of compounds (e.g., the oxide film shown in Figure 10 contained nitrides, which did not exist in the oxide shown in Figure 8 and Table I). Meanwhile, the growth process of oxide films in the oxidation cell revealed the evolution of the gas components contained in the entrained gases (i.e., the early oxide film shown in Figure 11(c) contained $\mathrm{MgF}_{2}$ only, but the later oxide films shown in Figure 11(c) contained $\mathrm{MgS}$ or $\mathrm{MgSO}_{4}$ ).

Therefore, thermodynamic calculations were carried out, using the HSC simulation software from Outotec (h ttp://www.hsc-chemistry.net), to investigate the reactions which could cause the spectrum of compositions 



Fig. 10 - (a) An entrainment defect on the fracture surface of another commercial-purity Mg alloy test bar, (b) spectrum of the oxide film (the acceleration voltage was $5 \mathrm{kV}$ ), indicating nitride contained in the oxide film, and $(c)$ a magnified observation of the oxide film.

within the entrainment defects (i.e., where the entrapped gas reacted with the surrounding commercially pure Mg-alloy melt). The determination of the most likely products was calculated using Gibbs free energy based simulations for the reaction processes between a small amount of cover gas (i.e., the amount in a trapped bubble) and the liquid $\mathrm{Mg}$.

The simulations assumed $7 \times 10^{-7} \mathrm{~kg}$ cover gas of 0.5 pet $\quad \mathrm{SF}_{6} /$ air (approximate $0.57 \mathrm{~cm}^{3}$ or $3.14 \times 10^{-8} \mathrm{kmol}$ ) with a matched amount of $\mathrm{Mg}$ (i.e., a theoretical amount to complete all possible reactions with the trapped gas). Previous works indicated that the $\mathrm{SF}_{6}$ could decompose into $\mathrm{SF}_{5}, \mathrm{SF}_{4}, \mathrm{SF}_{3}, \mathrm{SF}_{2}, \mathrm{~F}_{2}, \mathrm{~S}(\mathrm{~g})$, $\mathrm{S}_{2}(\mathrm{~g})$ and $\mathrm{F}(\mathrm{g}) \cdot{ }^{[34-37]}$ Hydrogen was assumed not affecting the reactions, due to the decomposition of $\mathrm{Mg}(\mathrm{OH})_{2}$ at $332{ }^{\circ} \mathrm{C} \cdot{ }^{[38]}$

The thermodynamic calculation of the reactions between the $\mathrm{Mg}$ and trapped gases $\left(\mathrm{SF}_{6} /\right.$ air $)$ is presented in Figure 15. Reactants and products less than $1 \times 10^{-15} \mathrm{kmol}$ are not shown in this figure due to their relatively small quantities by at least 5 orders of magnitude when compared with $\mathrm{SF}_{6}$ $\left(\approx 1.57 \times 10^{-10} \mathrm{kmol}\right)$. The whole reaction process of both in $\mathrm{SF}_{6} /$ air could be divided into the following 3 stages.
In Stage $1, \mathrm{MgF}_{2}$ formed due to the preferential consumption of all fluorides, while accumulated sulfur in the residual gas reacted with $\mathrm{O}_{2}$ to form $\mathrm{SO}_{2}$ which is consistent with the oxide films shown in Figure 11. Sulfur-containing compounds did not exist in the oxide film held for 0 minute in Figure 11(a), but was found in the oxide film when the holding time increased to 5 minutes (Figure 11(b)). Therefore, the oxide film shown in Figure 11(a) may correspond to the reaction stage 1. If hydrogen were in the melt at this stage it would diffuse from the $\mathrm{Mg}$ melt into the defect rather than affect the reactions. The oxide film may have contained fluorides only, as shown by the single-layered film in Figure 16(a).

In Stage 2, all fluorides in the entrained gas were depleted in the 0.5 pct $\mathrm{SF}_{6} /$ air. $\mathrm{SO}_{2}$ and $\mathrm{O}_{2}$ reacted with the liquid $\mathrm{Mg}$, producing $\mathrm{MgSO}_{4}$ and $\mathrm{MgO}$ in the oxide film. Since a F-enriched film during stage 1 already existed on the melt surface, the $\mathrm{MgSO}_{4}$ and $\mathrm{MgO}$ formed an additional S-enriched layer upon the F-enriched layer, hence the double-layer structure shown in Figures 11(b) and (c). The entrainment defect shown in Figure 6 and Figure 8 may correspond to this reaction stage. In addition, as shown in Figure $13, \mathrm{MgSO}_{4}$ was only produced in the early period of the stage 2 . In the late period, only $\mathrm{MgO}$ was produced. This may be the 

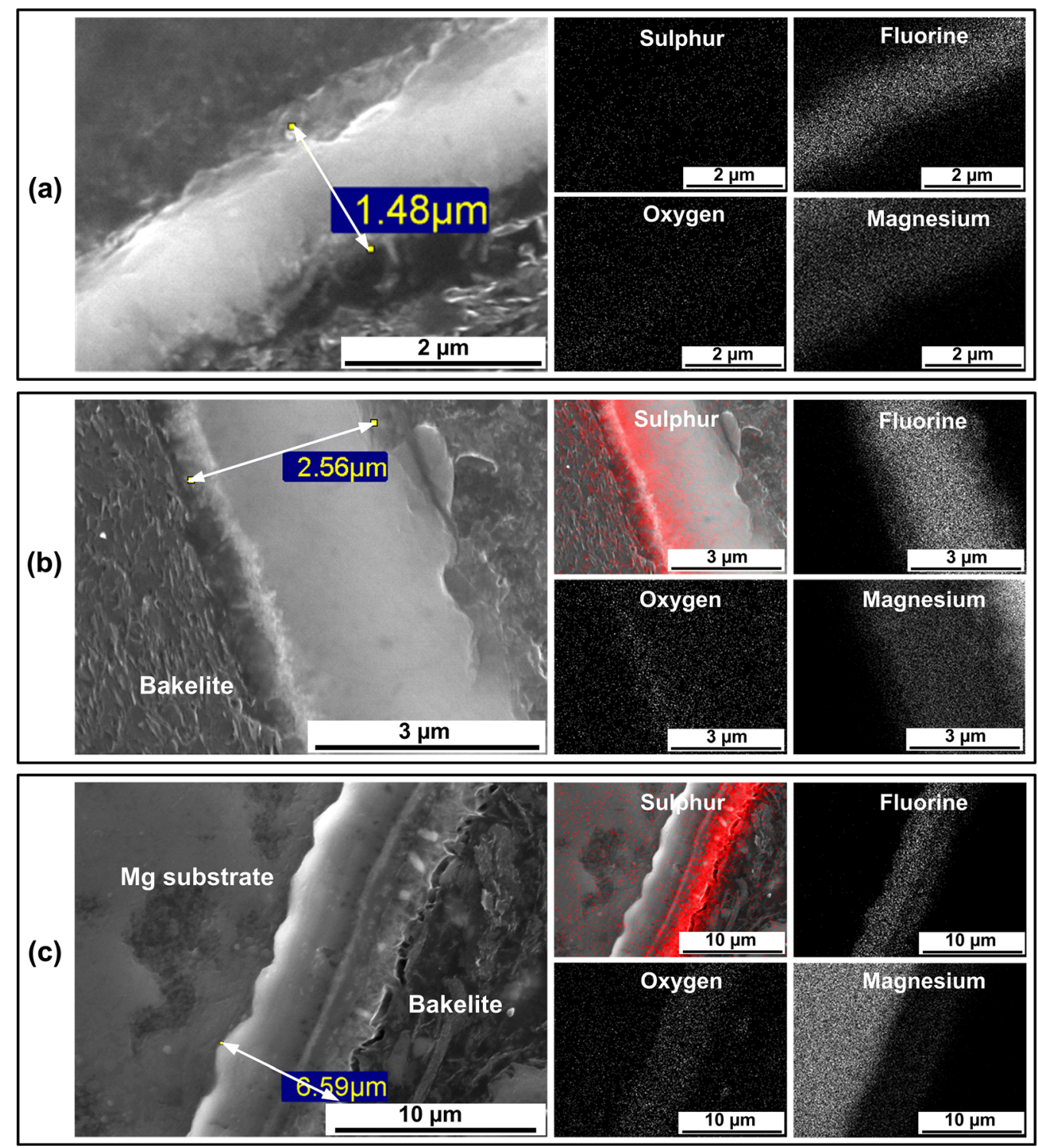

Fig. 11-Surface films on the liquid $\mathrm{Mg}$ alloy formed in the sealed oxidation cell that was held for different time in $\mathrm{SF}_{6} /$ air and their EDS mapping: (a) $0 \mathrm{~min}$; (b) $5 \mathrm{~min}$, and (c) $30 \mathrm{~min}$.

reason why the inner section of the defect shown in Figure 6(a) contained a feature composed of $\mathrm{MgO}$ only, while its oxide film contained a small amount of $\mathrm{MgSO}_{4}$. Figure 16(b) shows schematic of entrainment defects corresponding to this reaction stage.

In Stage 3, $\mathrm{MgSO}_{4}$ reacted with the liquid magnesium, forming $\mathrm{MgS}$ and $\mathrm{MgO}$ in the oxide film. Then the $\mathrm{Mg}$-alloy melt reacted with nitrogen in the residual gases, forming $\mathrm{Mg}_{3} \mathrm{~N}_{2}$ until all other reactions were completed. The defect shown in Figure 10 may correspond to this reaction stage due to its nitrides content. The defect shown in Figure 7, of which entrained gas had been depleted, may also correspond to this stage. However, $\mathrm{Mg}_{3} \mathrm{~N}_{2}$ was not detected in its oxide film bonding layer, which may be due to the hydrolyzation of $\mathrm{Mg}_{3} \mathrm{~N}_{2}$ during the polishing process (i.e., using water as polishing liquid), as follows ${ }^{[30]}$ :

$$
\mathrm{Mg}_{3} \mathrm{~N}_{2}+6 \mathrm{H}_{2} \mathrm{O}=3 \mathrm{Mg}(\mathrm{OH})_{2}+2 \mathrm{NH}_{3}
$$

Figure 16(c) shows schematic of the entrainment defects corresponding to this reaction stage. The reaction stages 1-3 indicate that the entrained gases in a $\mathrm{Mg}$-alloy melt using $\mathrm{SF}_{6} /$ air could be depleted due to the reaction with the surrounding liquid $\mathrm{Mg}$-alloy. This process differs from that of Al-alloys i.e., an entrained gas (air) in Al-alloys is very difficult to deplete since aluminum does not readily react with nitrogen ${ }^{[13,14]}$ ).

It should be noted that, the contact area of Mg-alloy melt and cover gases in the oxidation cell is relatively small considering the large volume of melt and gases, therefore the holding time for the reaction in the oxidation cell was long (5min - 30min) and impractical for a practical casting. However, it is worth noting that the entrainment defects in real casting could be very 

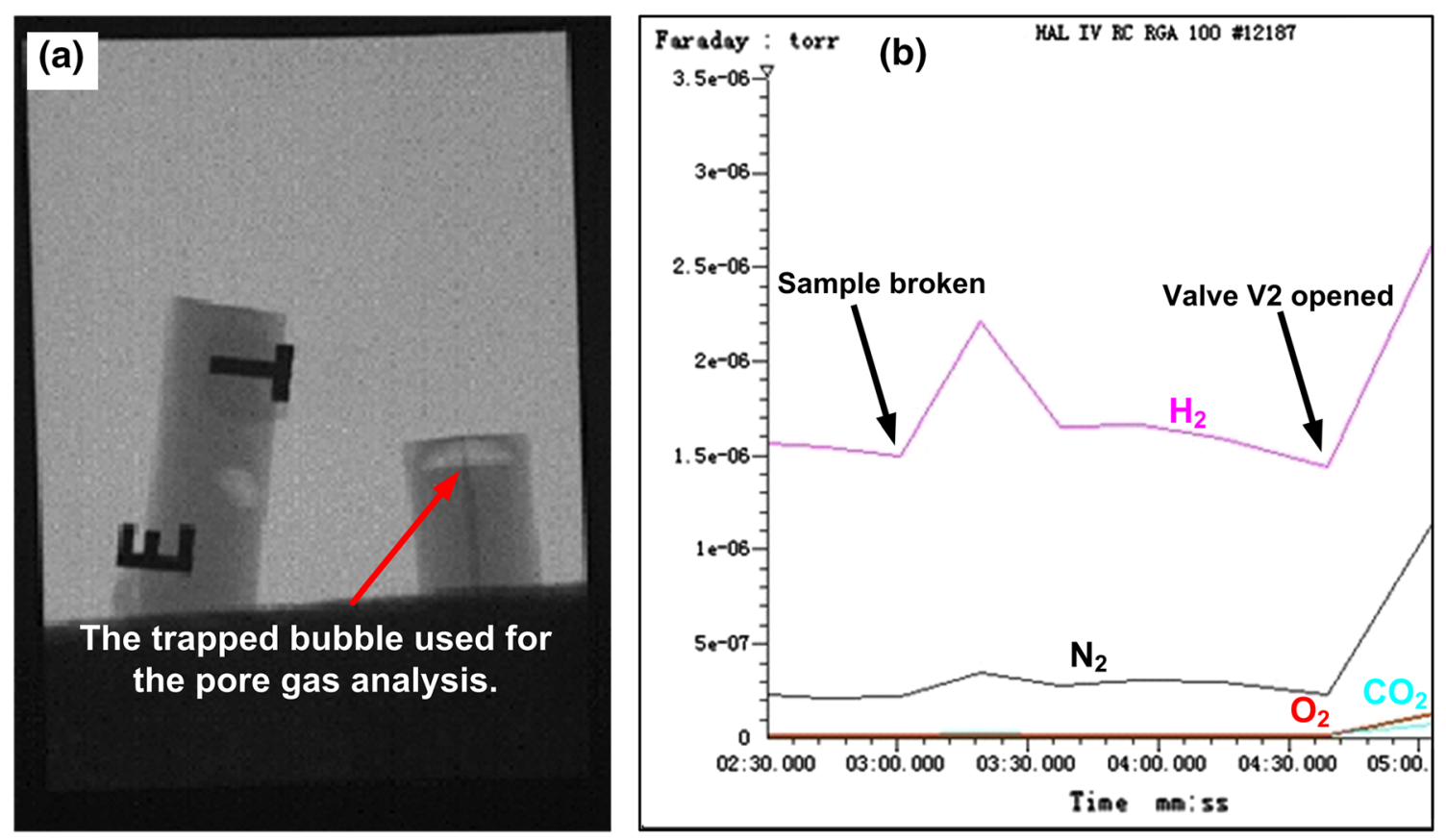

Fig. 12-(a) X-ray image of a trapped bubble contained in the casting under 0.5 pct $\mathrm{SF}_{6} /$ air and $(b)$ mass spectroscopy result of the pore gas analysis.

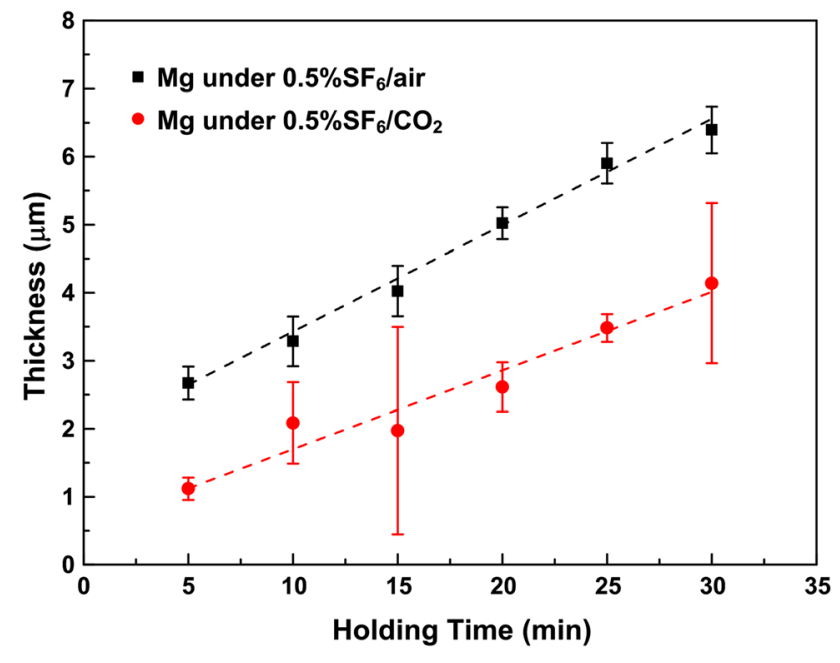

Fig. 13 - Comparison of the oxide film growth rates in 0.5 pct $\mathrm{SF}_{6} /$ air and 0.5 pet $\mathrm{SF}_{6} / \mathrm{CO}_{2}$.

small (as small as a few micrometers ${ }^{[10]}$ ), and the entrained gas could be in great contact with the surrounding melt, forming a relatively large contact area, which could cause faster consumption of the entrained gases. Moreover, a Mg-alloy sand casting would normally solidify within a few minutes (e.g., a $60 \mathrm{~mm}$ diameter casting expecting to take in the order of 4 min to fully solidify ${ }^{[39]}$, , suggesting that the Mg-alloy

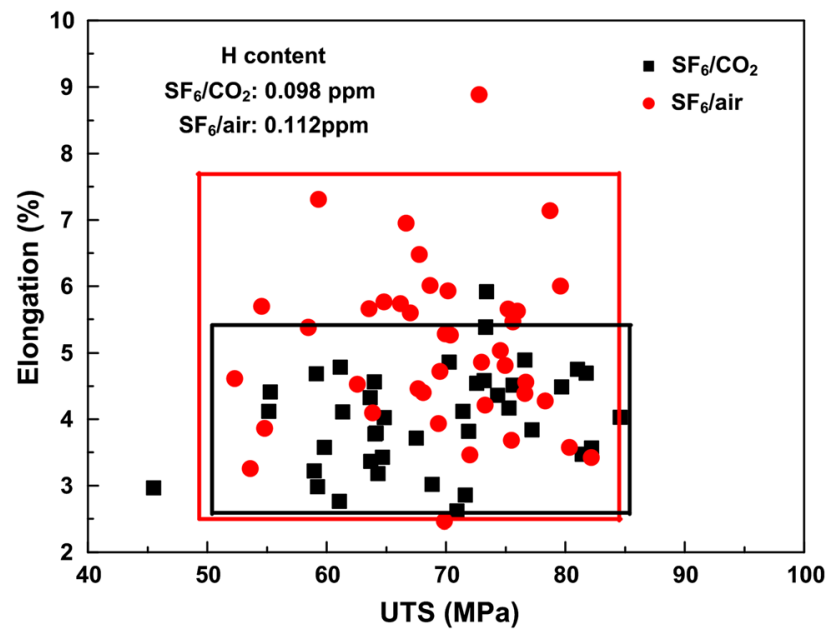

Fig. 14-2-sigma diagram of the mechanical properties of the commercial-purity $\mathrm{Mg}$-alloy castings produced in $0.5 \mathrm{pet} \mathrm{SF}_{6} /$ air and 0.5 pet $\mathrm{SF}_{6} / \mathrm{CO}_{2}$.

casting may likely contain some entrainment defects with depleted entrained gas, which indicates the potential to diminish the negative effect of the defects.

In addition, the size of the contact area between the entrained gases and the surrounding melt may vary depending on the sizes and shapes of entrainment defects. Thus, the consumption speed of the entrained gases (as well as the growth rate of the oxide films) may 




Fig. 15-An equilibrium diagram for the reaction at 1 atm and $700{ }^{\circ} \mathrm{C}$ with $7 \mathrm{e}-7 \mathrm{~kg}$ gas of $0.5 \mathrm{pct} \mathrm{SF}_{6} /$ air. The $\mathrm{X}$-axis is the amount of $\mathrm{Mg}$ having reacted with the entrained gas, and the vertical $\mathrm{Y}$-axis denotes the amounts of the reactants and products. also differ, as this would be dependent on the sizes and shapes of the entrapped bubbles. This may be the reason why the defects formed in the same casting corresponded to different reaction stages in the suggested evolution model i.e., Figure 8 corresponds to stage 2, while Figure 10 corresponds to stage 3.

\section{B. The Effect of Carrier Gases on the Quality of Mg-Alloy Castings}

As discussed above, the entrained gas within a Mg-alloy casting can be consumed due to the reaction with the surrounding melt. The entrained gas was therefore transferred to solid compounds, which could reduce both the defect size and void volume within the entrainment defects (e.g., if an entrained gas of air was depleted by the surrounding liquid $\mathrm{Mg}$-alloy, under an assumption that the melt temperature is $700{ }^{\circ} \mathrm{C}$ and the depth of liquid Mg-alloy is $10 \mathrm{~cm}$, the total volume of the final solid products would be 0.044 pet of the air
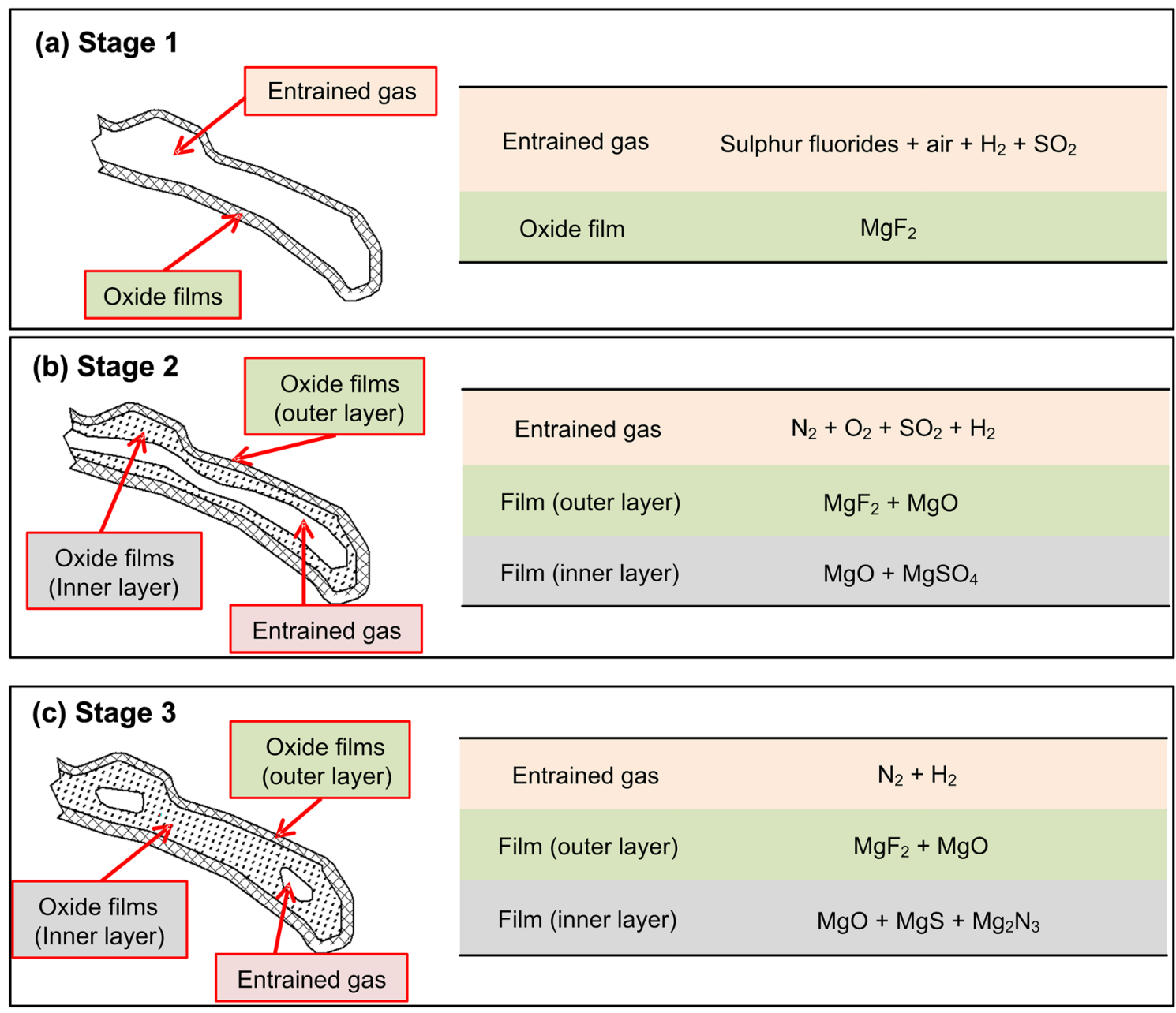

Fig. 16 - Schematic of the double oxide film defects corresponding to the three reaction stages under different atmospheres shown in Figure 15: (a) stage 1 , (b) stage 2 , and (c) stage 3 . 
volume). The negative effect of entrainment defects on the quality of Mg-alloy castings may consequently become diminished. Hence the consumption rate of the entrained gases could be a critical parameter for diminishing the negative effect of the entrainment defects.

The oxide film growth rates shown in Figure 13 indicated that an entrained gas of $\mathrm{SF}_{6} /$ air had a higher consumption rate compared with that of $\mathrm{SF}_{6} / \mathrm{CO}_{2}$, suggesting that the use of air instead of $\mathrm{CO}_{2}$ could promote the entrained gas consumption, and therefore increase the final casting properties. This method was subsequently supported by the UTS and elongation datasets of the castings produced in different carrier gases (i.e., air and $\mathrm{CO}_{2}$, shown in Figure 14), which showed that the casting produced in $\mathrm{SF}_{6} /$ air statistically had a better elongation than that produced in $\mathrm{SF}_{6} / \mathrm{CO}_{2}$.

Although the void volume within the entrainment defects could be significantly reduced, causing the oxide film to grow together, the residual sandwich-like structure (as shown in Figure 7) was a non-metallic inclusion, which was still harmful for the mechanical properties of castings. This might be the reason why the difference of the casting properties shown in Figure 14 were not significant, especially for the UTS datasets. However, it should be noted that the castings produced in $\mathrm{SF}_{6} /$ air was widely expected to be lower than that produced in $\mathrm{SF}_{6} / \mathrm{CO}_{2}$, since the low protectability of air would cause a higher content of oxide particles in the melt. Therefore, the small difference of the UTS datasets shown in Figure 14 still indicated a positive effect of the relatively faster entrained gas consumption rate of air.

In addition, it should be noted that not all Mg-alloy foundries follow the casting process described in the present work. The Mg-alloy melt in present work was degassed, thus reducing the effect of hydrogen on the consumption of entrained gas (i.e., hydrogen could diffuse into the entrained gas, thus suppressing the depletion of the entrained gas $\left.{ }^{[10,12,32]}\right)$. In contrast, in the Mg-alloy industry, it was widely believed that there is not a 'gas problem' with magnesium. ${ }^{[40]}$ Although some studies have shown the negative effect of hydrogen on the mechanical properties of Mg-alloy casting, ${ }^{[24,25]}$ degassing processes are still not popular in $\mathrm{Mg}$-alloy foundries.

Moreover, in present work, the sand mold cavity was flushed with the $\mathrm{SF}_{6}$ cover gas prior to pouring. ${ }^{[41]}$ However, not all the Mg-alloy foundries flushed the mold cavities in this way. Some of them used sulfur powder instead of the cover gas flushing process (e.g., the Stone Foundry, UK). This cover-gas-flushing process was also not suitable for all the Mg-alloy casting process, such as the high pressure die casting (HPDC) process. Therefore, if the mold was not flushed by the cover gases, the entrained gases contained in the final castings would be different from the present work (e.g., air for HPDC castings, $\mathrm{SO}_{2}$ /air for the Stone Foundry's castings).

Therefore, it may be required a further investigation into the processes of different $\mathrm{Mg}$-alloy foundries, to confirm the effect of carrier gas on the quality of different industrial Mg-alloy castings.

\section{CONCLUSION}

(1) The evolution of processes involved in the entrainment defects that occur during the casting process was examined experimentally and also with theoretical thermodynamic calculations mainly under the protection of $\mathrm{SF}_{6} /$ air. Fluorides found in the entrained gases appeared to be preferentially consumed, while sulfur accumulated in the residual gases. The oxide films had different structures and contained different combinations of compounds, depending on which reaction stage the defect was in. The entrained cover gases contained within the defects could be depleted, forming a sandwich-like structure. Such structure should be encouraged as the consumption of these entrained gases could have the potential to diminish the entrainment defects and further improve the quality of $\mathrm{Mg}$ castings.

(2) Entrained $\mathrm{SF}_{6}$ /air gases were consumed more rapidly than entrained $\mathrm{SF}_{6} / \mathrm{CO}_{2}$, resulting in a faster growing oxide film which had a greater chance of reducing the size and void volume of entrainment defects. This is supported by tensile test results which shows that 40 pct of elongation data point from the commercial-purity $\mathrm{Mg}$-alloy casting produced in 0.5 pet $\mathrm{SF}_{6} /$ air were comparatively higher than nearly all of those produced in 0.5 pct $\mathrm{SF}_{6} / \mathrm{CO}_{2}$ cover gases.

\section{ACKNOWLEDGMENT}

The casting samples were produced by the Casting Laboratory of the University of Birmingham. This work was supported by the EPSRC LiME grant EP/ $\mathrm{H} 026177 / 1$, and the authors acknowledge the help from Dr W.D. Griffiths and Mr. Adrian Carden.

\section{CONFLICT OF INTEREST}

On behalf of all authors, the corresponding author states that there is no conflict of interest.

\section{OPEN ACCESS}

This article is licensed under a Creative Commons Attribution 4.0 International License, which permits use, sharing, adaptation, distribution and reproduction in any medium or format, as long as you give appropriate credit to the original author(s) and the source, provide a link to the Creative Commons licence, and indicate if changes were made. The images or other third party material in this article are included in the article's Creative Commons licence, unless indicated otherwise in a credit line to the material. If material is not included in the article's Creative Commons licence and your intended use is not permitted by statutory regulation or exceeds the permitted use, you will need to obtain permission directly from the copyright hold- 
er. To view a copy of this licence, visit http://creativec ommons.org/licenses/by/4.0/.

\section{REFERENCES}

1. M.C.S.: Reston, Virginia, 2020, p. https://doi.org/10.3133/mcs20 20.

2. M.C.S.: Reston, Virginia, 2019, p. https://doi.org/10.3133/702024 34.

3. F. Yavari and S.G. Shabestari: Metall. Mater. Trans. B, 2020, vol. 51B, pp. 3089-97.

4. D. Luo, Y. Liu, X. Yin, H. Wang, Z. Han, and L. Ren: J. Alloys Compd., 2018, vol. 731, pp. 731-38.

5. A.S.H. Kabir, S. Jing, and S. Yue: Metall. Mater. Trans. B, 2016, vol. 47B, pp. 3326-32.

6. Y. Wan, B. Tang, Y. Gao, L. Tang, G. Sha, B. Zhang, N. Liang, C. Liu, S. Jiang, Z. Chen, X. Guo, and Y. Zhao: Acta Mater., 2020, vol. 200, pp. 274-86.

7. J Campbell: Oxford: Elsevier Butterworth-Heinemann.

8. W.D. Griffiths and N.-W. Lai: Metall. Mater. Trans. A, 2007, vol. 38A, pp. 190-96.

9. A.R. Mirak, M. Divandari, S.M.A. Boutorabi, and J. Campbell: Int. J. Cast Met. Res., 2007, vol. 20, pp. 215-20.

10. J. Campbell: Butterworth-Heinemann, Oxford, 2004.

11. M. Aryafar, R. Raiszadeh, and A. Shalbafzadeh: J. Mater. Sci., 2010, vol. 45, pp. 3041-51.

12. R. Raiszadeh and W.D. Griffiths: Metall. Mater. Trans. B, 2011, vol. 42B, pp. 133-43.

13. H. Scholz and P. Greil: J. Mater. Sci., 1991, vol. 26, pp. 669-77.

14. S.S.S. Kumari, U.T.S. Pillai, and B.C. Pai: J. Alloys Compd., 2011, vol. 509, pp. 2503-09.

15. S. Bartos: 131st TMS Annual Meeting, Washington, February 17-21, 2002.

16. Y. Jia, J. Hou, H. Wang, Q. Le, Q. Lan, X. Chen, and L. Bao: $J$. Mater. Process. Technol., 2020, vol. 278, p. 116542.

17. S. Ouyang, G. Yang, H. Qin, S. Luo, L. Xiao, and W. Jie: Mater. Sci. Eng. A, 2020, vol. 780, p. 139138.

18. S.-M. Xiong and X.-F. Wang: Trans. Nonferr. Metals Soc. China, 2010, vol. 20, pp. 1228-34.

19. Tian Li and JMT Davies: Metall. Mater. Trans. A, 2020, vol. 51A, pp. 5389-5400.

20. Shou.-Mei. Xiong and Xiao.-Long. Liu: Metall. Mater. Trans. A, 2007, vol. 38A, pp. 428-34.
21. G. Pettersen, E. Øvrelid, G. Tranell, J. Fenstad, and H. Gjestland: Mater. Sci. Eng. A, 2002, vol. 332, pp. 285-94.

22. B. D. Lee, U. H. Beak, K. W. Lee, G. S. Han and J. W. Han: Mater. Trans., 2013, p. M2012057.

23. T.-S. Shih, J.-B. Liu, and P.-S. Wei: Mater. Chem. Phys., 2007, vol. 104, pp. 497-504.

24. A. Elsayed, S.L. Sin, E. Vandersluis, J. Hill, S. Ahmad, and C. Ravindran: AFS Trans. Am. Foundry Soc., 2012, vol. 120, p. 423.

25. E. Zhang, G.J. Wang, and Z.C. Hu: Mater. Sci. Technol., 2010, vol. 26, pp. $1253-58$.

26. H. E. Friedrich and B. L. Mordike: Magnesium Technology. Springer, 2006.

27. F. Liu, L. Yang, Y. Huang, P. Jiang, G. Li, W. Jiang, X. Liu, and Z. Fan: J. Manuf. Process., 2017, vol. 30, pp. 313-19.

28. Q. Chen and W.D. Griffiths: Metall. Mater. Trans. A, 2017, vol. 48A, pp. 5688-98.

29. Q.G. Wang, D. Apelian, and D.A. Lados: J. Light Met., 2001, vol. 1, pp. 73-84.

30. C. Bauer, A. Mogessie, and U. Galovsky: Z. Metall., 2006, vol. 97, pp. $164-68$.

31. S.S. Wu, S.X. Xu, Y. Fukuda, and H. Nakae: Int. J. Cast Met. Res., 2008, vol. 21, pp. 100-04.

32. Y. Yue, W.D. Griffiths, J.L. Fife and N.R. Green: In Proceedings of the 1st International Conference on 3D Materials Science, Springer, 2012, pp 131-36.

33. L. Bütikofer, B. Stawarczyk, and M. Roos: Dental Mater., 2015, vol. 31 , pp. e33-50.

34. S. Hayashi, W. Minami, T. Oguchi, and H.-J. Kim: Kagaku Kogaku Ronbunshu, 2009, vol. 35, pp. 411-15.

35. K. Aarstad: Protective Films on Molten Magnesium, Norwegian University of Science and Technology, 2004.

36. R.L. Wilkins: J. Chem. Phys., 1969, vol. 51, pp. 853-54.

37. K. Hesselemam O. Kubaschewski: Springer, Belin, 1991.

38. L.A. Hollingbery and T.R. Hull: Thermochim. Acta, 2010, vol. 509 , pp. $1-11$.

39. E. Guo, L. Wang, Y. Feng, L. Wang, and Y. Chen: J. Therm. Anal. Calorim., 2019, vol. 135, pp. 2001-08.

40. Z.C. Hu, E.L. Zhang, and S.Y. Zeng: Mater. Sci. Technol., 2008, vol. 24, pp. 1304-08.

41. C. Cingi: Mold-Metal Reactions in Magnesium Investment Castings. Helsinki University of Technology, 2006.

Publisher's Note Springer Nature remains neutral with regard to jurisdictional claims in published maps and institutional affiliations. 